\title{
Ekmek İsrafını Önleme Konulu Sosyal Sorumluluk Kampanyasına iliş̧kin Akademisyen, Uzman ve Öğrenci Görüşleri
}

\author{
Prof. Dr. Adnan Tepecik \\ Yar. Doç. Dr. Çağrı Gümüş

\section{Özet}

Makale Geliş Tarihi: 02.08.2016

Yayına Kabul Tarihi: 05.05.2017

Bu araştırmanın temel amacı; hedef kitleyi bilinçlendirmek ve eğitmek için ekmek israfinı önleme konulu sosyal sorumluluk kampanyasının hangi aşamalardan geçerek hazırlanması gerektiğini, "örnek bir sosyal sorumluluk kampanyası" ile ele alarak öğretim elemanı, uzman ve hedef kitle olan öğrenci görüşlerine sunmaktır. Araştırmada tarama modeli kapsamında, literatürden ve alan uzmanları ile yapılan görüşmelerden yararlanılmıştır. Araştırmanın çalışma grubunu grafik ve iletişim tasarımı alanlarından rastgele seçilen 30 öğretim elemanı ve sektörde çalışan 30 uzman, ve yaş aralığı I4- I 8 olan ve Ankara'nın farklı semtlerinde (Mamak, Bahçelievler ve Çankaya) göreceli olarak alt, orta ve orta üst gelir seviyesine sahip çalışmanın hedef kitlesini oluşturan ikinci kademe ilköğretim öğrencilerinden 35'i kız, 55’i erkek olmak üzere toplam 90 kişi oluşturmaktadır. Kampanyanın değerlendirilmesi amacı ile uzman grubun denetiminde 4'lü derecelendirme ölçeği hazırlanmış ve kontrol listesi kullanılmıştır. Hazırlanan ölçek çalışma grubuna kampanya bizzat gösterilerek araştırmacı tarafindan birebir uygulanmıştır. Araştırma sonucunda elde edilen bulgulara göre; araştırmaya katılan ve hedef kitle olan öğrencilerin çoğunluğunun ekmek israfının nedeni olarak ihtiyaçtan fazla ekmek alımı olduğunu saptanmıştır.

Anahtar Sözcükler: Sosyal Sorumluluk, Sosyal Sorumluluk Kampanyaları, Ekmek İsrafı, Ekmek İsrafı Önleme Kampanyası

\section{THE OPINIONS OF THE ACADEMICS, SPECIALISTS AND STUDENTS ABOUT THE SOCIAL RESPONSIBILITY CAMPAIGN FOR PREVENTING BREAD WASTE}

\begin{abstract}
The main purpose of this research is to discuss which stages the social responsibility campaign that is conducted to make the target audience conscious about bread waste prevention should follow by handling "an example social responsibility campaign" and to present it to opinions of the faculty members, specialists and the students that are target audience. In the research, as a scanning model, the literature and the interviews that are conducted with specialists of the field are used. The working group of the research is constructed on randomly selected 30 faculty members from departments of the graphic and communication design and 30 specialists from the sector, the study is constituted on 90 elementary school students ( 35 girls and 55 boys) that are between the ages 14-18, living in the different districts of Ankara (Mamak, Bahçelievler and Çankaya) and belonging to different social classes (downscale, middle and upper middle). For evaluating the campaign, a quartet assessment scale is prepared and a control list is used. The scale is applied by showing the campaign to the working group by the researcher. Additionally, for the campaign, a survey is structured to be applied to the target audience of the campaign and it is applied to the audience by the researcher. According to the findings of the research; the students who attended the research who are the target audience stated that the cause of bread waste is buying more bread than that is needed.
\end{abstract}

Keywords: Social Responsibility, Social Responsibility Campaigns, Bread Waste, Bread Waste Prevention Campaign 


\section{Giriş}

Her birey var olduğu toplum içerisinde birtakım haklar kazanmakta ve bir takım görevler üstlenmektedir. Bireylerin içinde var olduğu topluma, ülkeye ve hatta dünyaya yönelik çeşitli sorumlulukları bulunmaktadır. Sorumluluk kavramı; "kişinin kendi davranışlarını veya kendi yetki alanına giren herhangi bir olayın sonuçlarını üstlenmesi, sorum, mesuliyet" anlamına gelmektedir ${ }^{1}$. Bu doğrultuda bireylerden oluşan her grup da birleşme amaçları çerçevesinde çeşitli sorumluluklara sahiptir. Kurumlarında tıpkı bireyler gibi içinde bulunduğu toplum, ülke ve uluslararası çevre bağlamında sosyal ve ekonomik sorumluluklara sahiptir.

$\mathrm{Bu}$ bağlamda; sosyal sorumluluk kavramı, özünde tüm bireylerin, kurumların çevreye ve topluma karşı yapması gerekenler olduğunu ifade ederken, genelde daha çok kurumların sosyal sorumlulukları anlamında da kullanılmaktadır. Sosyal sorumluluk anlayışına göre; düne kadar kar arttırma güdüsüyle ortaklarına karşı sorumlulukları olan kurumların bugün sorumluluk alanları genişlemiştir. Günümüzde kurumlardan beklenen çevre sorunları, çalışan hakları, insan hakları gibi konularda topluma fayda sağlayan ve gönüllük esasına dayalı çalışmalar yapmasıdır (Karahan, 2006: 1).

Günümüz koşullarının yarattığı yabancılaşma ve stres; alkol, uyuşturucu, sigara bağımlılığı gibi birçok sorunu da beraberinde getirmektedir. Bunun yanı sıra toplum huzurunu tehdit eden açlık, şiddet, çevre kirliliği ve AIDS gibi birçok sorun da çözüm beklemektedir. Büyüyen bu sorunlara müdahalede devlet tek başına yeterli olamamaktadır. Ancak sorunların çözüme ulaşmadan devam etmesi, toplumsal huzuru, mutluluğu, huzuru bozmakta ve çöküntüye sebep olmaktadır. Bu nedenle devletin çabalarının yanı aynı zamanda sivil toplum kuruluşları ve vakıflar kurularak, bu tür toplumsal sorunların çözümünde katkı sağlanmaya çalışılmaktadır. Tüm bunlar bazı fikirlerin topluma benimsetilmesi, düşünce ve davranış kalıplarında gerekli değişikliklerin yapılabilmesi, geniş yankılar uyandıracak sosyal sorumluluk kampanyaları gerektirmektedir (Bayraktaroğlu, 2007: 119).

Sosyal sorumluluk kampanyaları bir kurumu ya da bireyi belirli süre, dönem ve bir hareket planı içerisinde ilgili bir sosyal amaç ya da soruna, karşılıklı fayda sağlamak üzere bağlayan çeşitli mecraların kullanıldığı stratejik konumlandırma ve pazarlama aracı olarak tanımlanabilir (Elden, 2009: 302). Kurumlar sosyal sorumluluk kampanyalarıla belirli bir soruna katkı sağlarlar; aynı zamanda tüketiciyle duygusal bağ kurma ve medyada yer

I (www.tdk.gov.tr). 
bulma imkânına kavuşurlar. Uzun süreli ve başarılı kampanyalar; kurumun medyada haber olma imkânını ve tüketici gözünde kurumların beğenilirliğini arttırmaktadır. Sosyal bir kampanyayla ilgili medyada haber olmak, reklama karşı tepkili olan kişilerin bile ilgisini çekebilecek; zihinlerinde kurumla ile ilgili dolaylı yoldan olumlu yargılar oluşturabilecektir (Karahan, 2006: 62).

Kampanya ve grafik tasarım kavramları birbiriyle iç içe geçmiş kavramlardır. Sosyal sorumluluk kampanyalarının, hedef kitle üzerinde etkili olmalarının nedeni, içerdikleri her bilgi unsurunu görsel açıdan izleyiciye bilinçli bir şekilde aktarıyor olmalarındandır. Bu paralel de grafik tasarım, kampanyanın bilgi verme işlevini pekiştirmekte, kampanyanın verdiği bilginin yönünü belirlemekte ve doğru hedef kitleye ulaşmasında etkin rol oynamaktadır. (Nayman, 2008: 2).

Topluma fayda sağlamak amacı güden sivil toplum örgütleri, devlet kuruluşları, kurumlar, vakıflar; reklamların ve grafik tasarım ürünlerinin iletişim gücünü ve geniş kitlelere yayılma özelliğini görüp kendi amaçları için sosyal içerikli mesajlar veren çalışmalar (logo, açıkhava reklam, basılı reklam, toplu taşıma araçları içi-dışı, web sayfası ve reklam filmi) kullanmaktadırlar. Sosyal sorumluluk kampanyalarında hedeflenen amaçların gerçekleşmesi için grafik tasarımından yararlanılmaktadır.

Bilindiği gibi ekmek tüm dünya ülkelerinde ve ülkemizde beslenme dendiğinde ilk akla gelen gıda maddesidir. Bugün dünyada çok çeşitli gıda maddeleri üretiliyor olmasına rağmen, ekmek dünya ülkelerinin \% 53 'ünde toplam kalorinin \% 50'sini, dünya ülkelerinin \% 87'sinde ise alınan kalorinin \%30'dan fazlasını sağlamakta olup, az tüketildiği söylenen batı Avrupa ülkelerinde bile alınan proteinin \% 30'unu, karbonhidratların \% 50'sini ve B grubu vitaminlerinin \% 50'sini sağladığı belirtilmektedir (Özkaya 1992: 9).

Türkiye'de ekmeğin insanların günlük besin ihtiyaçlarının karşılanmasında çok önemli bir yeri vardır. Bugün ülkemizdeki ekmek tüketiminin ekonomik şartlar da göz önünde bulundurularak 400 grama yakın olduğu belirtilmektedir (Özkaya 1992: 10). Ekmeğin Türkiye'de beslenme açısından bu kadar önemli yer tutması; beslenme alışkanlığı, diğer besinlere oranla ucuzluğu, tok tutma özelliği, birçok yiyeceğe nötr gıda olduğundan katık olabilmesi, kolay elde edilebilmesi ile açılanabilir. Ekmek içerdiği yüksek oranda karbonhidrata dayalı enerji sağlayıc özelliğinin yanı sıra, bileşiminde bulunan protein, mineral madde, vitamin ve düşük yağ içeriği ile beslenmede önemli rol oynamaktadır (Öten ve Ünsal 2006). Temel gıda maddelerinin başında yer alan ekmek, ülkemizde günlük kalori gereksiniminin \% 44'ünü, protein gereksiniminin ise yaklaşık \% 50'sini karşılamaktadır. Beslenmemizde bu kadar önemli yere sahip olan tahıl ve tahıl ürünleri insan sağlığı üzerine 
de şüphesiz önemli etkilerde bulunmaktadır. Tahıllarla sağlanan diyet lifi yüksek ve düşük yağıı bir diyet, kalp hastalıkları, felç ve bazı kanser gibi kronik hastalıklara karşı vücudu korumaya yardım etmektedir. Ayrıca yüksek karbonhidratlı diyetler, yükseltilmiş kan lipit seviyesinin düşürülmesi ve bazı gastrointestinal hastalıkların tedavisine de yardımcı olur (Karaoğlu ve Kotancilar 2001: 102).

Toplumumuzda kutsal olarak değerlendirilen ve sofralarımızın baş tacı olan ekmek aynı zamanda alın terini paylaşmayı ve bereketi ifade etmektedir. Ekmeğe atledilen bütün kutsal değerlere ve faydalara rağmen gerek dünya da gerek ülkemizde en çok israf edilen gıda ürünü ekmek olduğu ortaya çıkmıştır. FAO'ya göre dünyamızda 1 yılda; ekonomik değeri 1 trilyon ABD dolarına karşılık gelen 1.3 milyar ton gıda israf ediliyor. Dünyadaki gıda kaybı ve israfının dörtte birinin önlenmesiyle bile, yetersiz beslenen 870 milyon insanın gıda ihtiyacı karşılanabilmekte, ayrıca ABD ve Kanada gibi gelişmiş ülkelerde, üretilen gıdanın yaklaşık \% 40 ',$A B$ ' de ise üretilen ekmeğin \%30'u israf ediliyor. Kültürümüzde kutsal bir yeri olmasına ve nimet olarak addedilmesine rağmen 2005 yılda \%5 olan ekmek israf oranı 2012 yılında yapılan araştırma sonucuna göre \%20 artışla \%6'ya yükselmiştir. Üretilen ekmeğin önemli bir kısmı ne yazık ki gıda olarak tüketilmeyip çöpe atılıyor. Ekmek israfı ile ilgili olarak 2012 yılında yapılan araştırmalara göre ülkemizde günde 6 milyon yılda 2 milyar ekmek israf ediliyor. İsrafın ülkemizde ekonomik olarak yükü olan yıllık 1,5 milyar TL ile her yıl 500 okulu 80 hastane ve 500 km bölünmüş yol yapılabilmektedir. Araştırma sonucunda ayrıca, ekmek israfının engellenmesi hususunda toplumuzun bilgilendirmeye intiyacı olduğu tespit edilmiştir.

$\mathrm{Bu}$ doğrultuda, araştırmanın amacl; hedef kitleyi bilinçlendirmek ve eğitmek amacıyla; Ekmek israfı konulu sosyal sorumluluk kampanya tasarımının hangi aşamalardan geçerek hazırlanması gerektiğini, "örnek bir sosyal sorumluluk kampanyası" ile ele alarak öğretim elemanı ve uzman görüşlerine sunmaktır.

\section{Yöntem}

Bu araştırmada tarama modeli kapsamında, literatürden, öğretim elemanı ve uzmanlar ve öğrencilerle yapılan görüşmelerden yararlanılmıştır. Öğretim elemanı ve uzman ve öğrencilerin görüşüne başvurulduğu için çalışma nicel bir araştırmadır. Bu araştırmanın evrenini yapılacak olan Sosyal Sorumluluk Kampanyası oluşturmaktadır. Örneklemi Ekmek İsrafını Önleme Sosyal Sorumluluk Kampanyası olarak belirlenmiştir. Araştırmanın çalışma grubu ise grafik ve iletişim tasarımı alanlarından rastgele seçilen 30 öğretim elemanı ve sektörde çalışan 30 uzman oluşturmaktadır. Çalışmanın 
arka plan araştırması yaş aralığı 14-18 olan ve Ankara'nın farklı semtlerinde (Mamak, Bahçelievler ve Çankaya) göreceli olarak alt, orta ve orta üst gelir seviyesine sahip çalışmanın hedef kitlesini oluşturan ikinci kademe ilköğretim öğrencilerinden 35'i kız, 55'i erkek olmak üzere toplam 90 kişi üzerinde yapılmıştır. Araştırmanın konusu ile ilgili geniş kapsamlı literatür taraması yapılmıştır. Sosyal sorumluluk kampanyası hazırlanması amacıyla 2 öğretim elemanı, 1 eğitim uzmanı, 1 metin yazarı, 1 iletişim uzmanı, 2 grafik tasarımı uzmanından oluşan bir uzman grup oluşturulmuştur. Öncelikle oluşturulacak kampanya ile ilgili strateji (amaç, problem tanımlandıve hedef kitle belirlendi) ve yaratıcı strateji (slogan ve hedef kitleye verilecek mesajlar hazırlandı.) geliştirilmiştir. Bu doğrultuda çeşitli mecralarda uygulanmak üzere bir sosyal sorumluluk kampanyası hazırlanmıştır. Hazırlanan sosyal sorumluluk kampanyasının değerlendirilmesi amacı ile uzman grubun denetiminde 4'lü değerlendirme ölçeği hazırlanmış ve grafik ve iletişim tasarımı alanlarından rastgele belirlenen 30 öğretim elemanı ve sektörde çalışan 30 uzmana ve çalışmanın hedef kitlesini oluşturan ikinci kademe ilköğretim öğrencilerine bizzat araştırmacı tarafından uygulanmıştır. Elde edilensonuçlardeğerlendirilmişvebulgulardoğrultusundasosyalsorumluluk kampanyası yeniden yapılandırılmıştır. Verilerin analizinde SPSS 16.0 (The Statistical Package for the Social Sciences) paket programı kullanılmıştır. Araştırmanın alt amaçlarına uygun olarak elde edilen verilerin analizinde yüzde frekans istatistikleri çıkarılmış olup gruplara göre karşılaştırmalarda $\mathrm{k}^{2}$ testi kullanılmıştır. Anlamlılık düzeyi 0.05 olarak hesaplanmıştır. Bu doğrultuda tablolar oluşturularak bulgular ortaya konmuştur.evrensel olarak kabul edilen ve yaşamın tüm alanlarında uygulanan bir değerler sistemi olarak görülmeye başlamıştır.

\section{Bulgular ve Yorumlar}

Ekmek israfı konulu sosyal sorumluluk kampanyasının stratejisine (problem tanımlama, amacın saptanması ve hedef kitlenin belirlenmesi) ilişkin öğretim elemanı, uzman ve hedef kitleyi oluşturan öğrencilerin görüşleri alınmış ve sonuçlar tablo 1., 2., ve 3. de verilmiştir. 


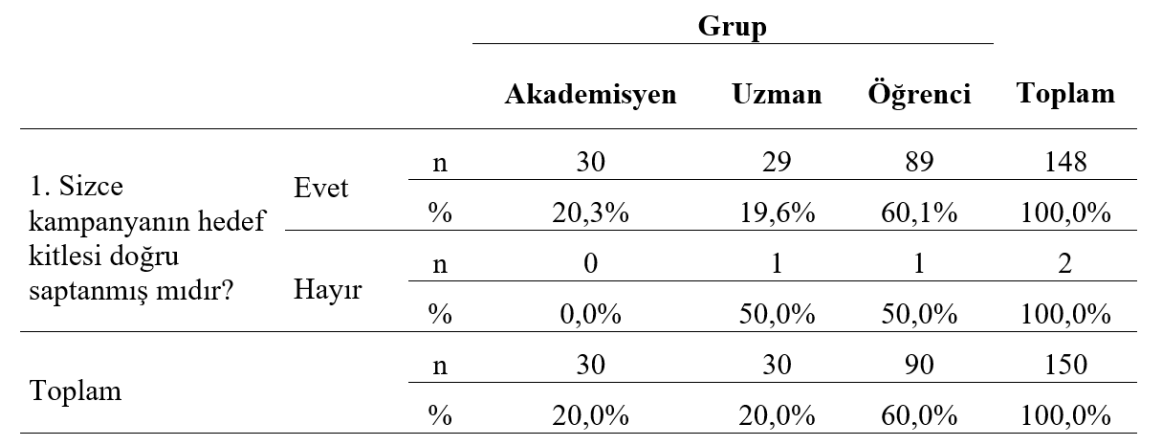

$\chi^{2}=1.351 \mathrm{p}=0,509$

Tablo I. Araştırma Grubunun Ekmek İsrafi Konulu Sosyal Sorumluluk Kampanyasının Hedef Kitlesine Illişkin Görüşleri

Kampanyanın hedef kitlesine yönelik soruya araştırmaya katılan grup içerisindeki (148 kişi) akademisyenlerin \% 20,3'ü, uzmanların \% 19,6'sı ve hedef kitle olan öğrencilerin \%60,1'i evet cevabını verirken; (2 kişi) uzman ve hedef kitleyi oluşturan öğrencilerin \%50'si hayır cevabını vermiştir. Akademisyen, uzman ve öğrencilere göre kampanyanın hedef kitlesi doğru saptanmıştır. İstatistiksel olarak da gruplara göre görüş farklılığı bulunmamaktadır ( $p>0.05$ ). Tablo 1'de görüldüğü üzere kampanyanın hedef kitlesinin doğru belirlendiği söylenebilir.

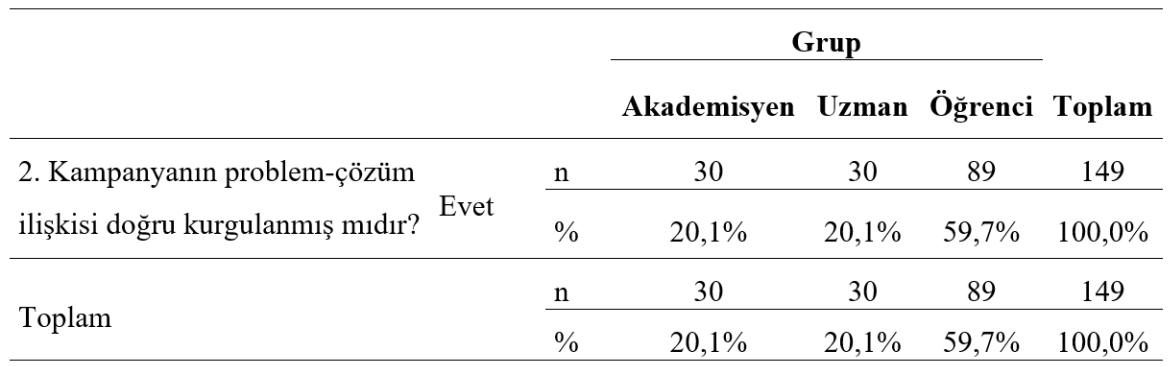

Tablo 2. Araştırma Grubunun Ekmek Israfi Konulu Sosyal Sorumluluk Kampanyasının Probleminin Saptanmasına lilş̧kin Görüşleri

Kampanyanın problem-çözüm ilişkisinin yani problemin saptanmasına ilişkin soruya araştırmaya katılan grup içerisindeki (149 kişi) akademisyenlerin $\% 20,1 ' i$, uzmanların \%20,1'i ve hedef kitle olan öğrencilerin \%59,7'si evet cevabını vermiştir. Tablo 2 'de görüldügü üzere kampanyanın problem-çözüm ilişkisi doğru saptandığı kampanya içerisinde çözümlendiği 
söylenebilir.

\begin{tabular}{|c|c|c|c|c|c|c|}
\hline & & & \multicolumn{3}{|c|}{ Grup } & \multirow[b]{2}{*}{ Toplam } \\
\hline & & & Akademisyen & Uzman & Öğrenci & \\
\hline \multirow{2}{*}{$\begin{array}{l}\text { 3. Kampanyanın amacı } \\
\text { anlaşılır biçimde } \\
\text { sunulmuș mudur? }\end{array}$} & \multirow[b]{2}{*}{ Evet } & $\mathrm{n}$ & 30 & 30 & 90 & 150 \\
\hline & & $\%$ & $20,0 \%$ & $20,0 \%$ & $60,0 \%$ & $100,0 \%$ \\
\hline \multirow{2}{*}{ Toplam } & & $\mathrm{n}$ & 30 & 30 & 90 & 150 \\
\hline & & $\%$ & $20,0 \%$ & $20,0 \%$ & $60,0 \%$ & $100,0 \%$ \\
\hline
\end{tabular}

Tablo 3. Araştırma Grubunun Ekmek İsrafi Konulu Sosyal Sorumluluk Kampanyasının Amacının Saptanmasına Illişkin Görüşleri

Kampanyanın problem-çözüm ilişkisinin yani problemin saptanmasına ilişkin soruya araştırmaya katılan grup içerisindeki (150 kişi) akademisyenlerin \%20'si, uzmanların \%20'si ve hedef kitle olan öğrencilerin \%60'ı evet cevabını vermiştir. Tablo 3'de görüldüğü üzere kampanyanın amacının anlaşılır biçimde saptandığı söylenebilir.

Ekmek israfı konulu sosyal sorumluluk kampanyasının yaratıcıstrateji (hedef kitleye verilecek slogan ve mesajların oluşturulması) ve tasarımına ilişkin öğretim elemanı uzman ve hedef kitleyi oluşturan öğrencilerin görüşleri alınmış ve sonuçlar tablo 4., 5., 6., 7., 8 ve 9' da verilmiştir.

\begin{tabular}{|c|c|c|c|c|c|c|}
\hline & & & \multicolumn{3}{|c|}{ Grup } & \multirow[b]{2}{*}{ Toplam } \\
\hline & & & Akademisyen & Uzman & Öğrenci & \\
\hline \multirow{6}{*}{$\begin{array}{l}\text { 4) Tasarımlarda } \\
\text { kullanılan renklerin } \\
\text { dikkat çekiciliği sizce } \\
\text { ne derecededir? }\end{array}$} & \multirow{2}{*}{ Çok iyi } & $\mathrm{n}$ & 21 & 20 & 63 & 104 \\
\hline & & $\%$ & $20,2 \%$ & $19,2 \%$ & $60,6 \%$ & $100,0 \%$ \\
\hline & \multirow{2}{*}{ İyi } & $\mathrm{n}$ & 8 & 8 & 24 & 40 \\
\hline & & $\%$ & $20,0 \%$ & $20,0 \%$ & $60,0 \%$ & $100,0 \%$ \\
\hline & \multirow{2}{*}{ Orta } & $\mathrm{n}$ & 1 & 2 & 3 & 6 \\
\hline & & $\%$ & $16,7 \%$ & $33,3 \%$ & $50,0 \%$ & $100,0 \%$ \\
\hline \multirow{2}{*}{ Toplam } & & $\mathrm{n}$ & 30 & 30 & 90 & 150 \\
\hline & & $\%$ & $20,0 \%$ & $20,0 \%$ & $60,0 \%$ & $100,0 \%$ \\
\hline
\end{tabular}

$\chi^{2}=0.705 \quad \mathrm{p}=0,951$

Tablo 4. Araştırma Grubunun Ekmek İsrafi Konulu Sosyal Sorumluluk

Kampanyasında Kullanılan Renklerin Dikkat Çekiciliğine İlişkin Görüşleri 
Kampanyanın tasarımlarında kullanılan renklerin dikkat çekiciliğine ilişkin soruya araştırmaya katılan grup içerisindeki (140 kişi) akademisyenlerin $\% 20,2$ 'si, uzmanların \% 19,2'si ve hedef kitle olan öğrencilerin \%60,3'ü çok iyi; (40 kişi) akademisyenlerin \% 20'si, uzmanların \% 20'si ve hedef kitle olan öğrencilerin \% 60'ı iyi; (6 kişi) akademisyenlerin \% 16,7'si, uzmanların \% 33,3'ü ve hedef kitle olan öğrencilerin \% 50'si orta cevabını vermişlerdir. Akademisyen, uzman ve öğrencilere göre tasarımlarda kullanılan renklerin dikkat çekiciliği "çok iyi" olarak değerlendirilmiştir. İstatistiksel olarak da gruplara göre tasarımlarda kullanılan renklerin dikkat çekiciliği konusunda görüş farklılığı bulunmamaktadır ( $p>0.05$ ). Tablo 4'de görüldüğü gibi kampanya tasarımlarında kullanılan renklerin oldukça dikkat çekici olduğu söylenebilir.

\begin{tabular}{|c|c|c|c|c|c|c|}
\hline & & & \multicolumn{3}{|c|}{ Grup } & \multirow[b]{2}{*}{ Toplan } \\
\hline & & & Akademisyen & Uzman & Öğrenci & \\
\hline \multirow{6}{*}{$\begin{array}{l}\text { 5) Sizce tasarımlarda } \\
\text { kullanılan tipografik } \\
\text { ögelerin okunurluğu } \\
\text { ne derecedir? }\end{array}$} & \multirow{2}{*}{ Çok iyi } & $\underline{\mathrm{n}}$ & 25 & 26 & 79 & 130 \\
\hline & & $\%$ & $19,2 \%$ & $20,0 \%$ & $60,8 \%$ & $100,0 \%$ \\
\hline & \multirow{2}{*}{ İyi } & $\underline{\mathrm{n}}$ & 5 & 3 & 10 & 18 \\
\hline & & $\%$ & $27,8 \%$ & $16,7 \%$ & $55,6 \%$ & $100,0 \%$ \\
\hline & \multirow{2}{*}{ Orta } & $\underline{\mathrm{n}}$ & 0 & 1 & 1 & 2 \\
\hline & & $\%$ & $0,0 \%$ & $50,0 \%$ & $50,0 \%$ & $100,0 \%$ \\
\hline \multirow{2}{*}{ Toplam } & & $\mathrm{n}$ & 30 & 30 & 90 & 150 \\
\hline & & $\%$ & $20,0 \%$ & $20,0 \%$ & $60,0 \%$ & $100,0 \%$ \\
\hline
\end{tabular}

$\chi^{2}=2.880 \quad \mathrm{p}=0,720$

Tablo 5. Araştırma Grubunun Ekmek Israfi Konulu Sosyal Sorumluluk Kampanyasında Kullanılan Tipografik Ögelerin Okunurluğuna İlişkin Görüşleri

Kampanyanın tasarımlarında kullanılan tipografik ögelerin okunurluğuna ilişkin soruya araştırmaya katılan grup içerisindeki (130 kişi) akademisyenlerin $\% 19,2$ si uzmanların \% 20 si ve hedef kitle olan öğrencilerin \% 60,8'i çok iyi; (18 kişi) akademisyenlerin \%27,8'i, uzmanların \%16,7'si ve hedef kitle olan öğrencilerin \% 55,6'sı iyi; (2 kişi) akademisyenlerin \% 20'si, uzmanların \%20'si ve hedef kitle olan öğrencilerin \%60'ı orta cevabını vermişlerdir. Akademisyen, uzman ve öğrencilere göre kullanılan tipografik ögelerin okunurluğunu "çok iyi" olarak değerlendirilmiştir. İstatistiksel olarak da gruplara göre kullanılan tipografik ögelerin okunurluğu konusunda görüş farklılığı bulunmamaktadır $(p>0.05)$. Tablo 5 'de görüldüğü gibi kampanya tasarımlarında kullanılan tipografik öğelerin okunur ve dikkat çekici olduğu söylenebilir. 


\begin{tabular}{|c|c|c|c|c|c|c|}
\hline & & & \multicolumn{3}{|c|}{ Grup } & \multirow[b]{2}{*}{ Toplam } \\
\hline & & & Akademisyen & Uzman & Öğrenci & \\
\hline \multirow{6}{*}{$\begin{array}{l}\text { 6) Tasarımlarda } \\
\text { kullanılan görsellerin } \\
\text { mesaja uygunluğu } \\
\text { sizce ne derecedir? }\end{array}$} & \multirow{2}{*}{ Çok iyi } & $\mathrm{n}$ & 23 & 26 & 76 & 125 \\
\hline & & $\%$ & $18,4 \%$ & $20,8 \%$ & $60,8 \%$ & $100,0 \%$ \\
\hline & \multirow{2}{*}{ İyi } & $\mathrm{n}$ & 7 & 3 & 14 & 24 \\
\hline & & $\%$ & $29,2 \%$ & $12,5 \%$ & $58,3 \%$ & $100,0 \%$ \\
\hline & \multirow{2}{*}{ Orta } & $\mathrm{n}$ & 0 & 1 & 0 & 1 \\
\hline & & $\%$ & $0,0 \%$ & $100,0 \%$ & $0,0 \%$ & $100,0 \%$ \\
\hline \multirow{2}{*}{ Toplam } & & $\mathrm{n}$ & 30 & 30 & 90 & 150 \\
\hline & & $\%$ & $20,0 \%$ & $20,0 \%$ & $60,0 \%$ & $100,0 \%$ \\
\hline
\end{tabular}

$\chi^{2}=5.908 \quad \mathrm{p}=0.206$

Tablo 6. Araştırma Grubunun Ekmek İsrafi Konulu Sosyal Sorumluluk Kampanyasında Kullanılan Görsellerin Mesaja Uygunluğuna Ilişkin Görüşleri

Kampanyanın tasarımlarında kullanılan tipografik ögelerin mesajın açıklanmasına uygunluğuna ilişkin soruya araştırmaya katılan grup içerisindeki (125 kişi) akademisyenlerin \% 18,4'ü, uzmanların \%20,8'i ve hedef kitle olan öğrencilerin \%60,8'i çok iyi; (24 kişi) akademisyenlerin \% 29,2'si, uzmanların \% 12,5'i ve hedef kitle olan öğrencilerin \%58,3'ü iyi; (1 kişi) ve uzmanların \%100'ü orta cevabını vermişlerdir. Akademisyen, uzman ve öğrencilere göre tasarımlarda kullanılan görsellerin mesaja uygunluğu "çok iyi" olarak değerlendirilmiştir. İstatistiksel olarak da gruplara göre tasarımlarda kullanılan görsellerin mesaja uygunluğu konusunda görüş farklılığı bulunmamaktadır ( $p>0.05$ ). Tablo 6 'da görüldüğü gibi kampanya tasarımlarında kullanılan görsellerin hedef kitleye verilmek istenen mesajların açıklanmasına uygun olduğu söylenebilir. 


\begin{tabular}{|c|c|c|c|c|c|c|}
\hline & & & \multicolumn{3}{|c|}{ Grup } & \multirow[b]{2}{*}{ Toplam } \\
\hline & & & Akademisyen & Uzman & Öğrenci & \\
\hline \multirow{6}{*}{$\begin{array}{l}\text { 7) Tasarımlardaki } \\
\text { görsel bütünlük sizce } \\
\text { ne derecedir? }\end{array}$} & \multirow{2}{*}{ Çok iyi } & $\mathrm{n}$ & 23 & 19 & 64 & 106 \\
\hline & & $\%$ & $21,7 \%$ & $17,9 \%$ & $60,4 \%$ & $100,0 \%$ \\
\hline & \multirow{2}{*}{ İyi } & $\mathrm{n}$ & 7 & 11 & 25 & 43 \\
\hline & & $\%$ & $16,3 \%$ & $25,6 \%$ & $58,1 \%$ & $100,0 \%$ \\
\hline & \multirow{2}{*}{ Orta } & $\mathrm{n}$ & 0 & 0 & 1 & 1 \\
\hline & & $\%$ & $0,0 \%$ & $0,0 \%$ & $100,0 \%$ & $100,0 \%$ \\
\hline \multirow{2}{*}{ Toplam } & & $\mathrm{n}$ & 30 & 30 & 90 & 150 \\
\hline & & $\%$ & $20,0 \%$ & $20,0 \%$ & $60,0 \%$ & $100,0 \%$ \\
\hline
\end{tabular}

$\chi^{2}=2.430 \quad \mathrm{p}=0.728$

Tablo 7. Araştırma Grubunun Ekmek İsrafi Konulu Sosyal Sorumluluk Kampanyasında Kullanılan Görsellerin Bütünlüğüne Ilişkin Görüşleri

Kampanyanın tasarımlarında kullanılan görsellerin bütünlüğüne ilişkin soruya araştırmaya katılan grup içerisindeki (106 kişi) akademisyenlerin $\% 21,7^{\prime}$ si, uzmanların \% 17,9'u ve hedef kitle olan öğrencilerin \%60,4'ü çok iyi; (43 kişi) akademisyenlerin \% 16,3'ü, uzmanların \% 25,6'sı ve hedef kitle olan öğrencilerin \%58,1'i iyi; ve (1 kişi) hedef kitle olan öğrencilerin $\% 100$ 'ü orta cevabını vermişlerdir. Akademisyen, uzman ve öğrencilere göre "tasarımlardaki görsel bütünlüğü "çok iyi" olarak değerlendirilmiştir. İstatistiksel olarak da gruplara göre Tasarımlardaki görsel bütünlük konusunda görüş farklılığı bulunmamaktadır $(p>0.05)$. Tablo 7'de görüldüğü gibi kampanya tasarımlarında kullanılan görsellerin strateji ve yaratıcı strateji açısından bütünlüklü olduğu söylenebilir. 


\begin{tabular}{|c|c|c|c|c|c|c|}
\hline & & & \multicolumn{3}{|c|}{ Grup } & \multirow[b]{2}{*}{ Toplam } \\
\hline & & & Akademisyen & Uzman & Öğrenci & \\
\hline \multirow{6}{*}{$\begin{array}{l}\text { 8) Tasarımların } \\
\text { içeriğiyle hedef kitleyi } \\
\text { bilgilendirme düzeyi } \\
\text { sizce ne derecedir? }\end{array}$} & \multirow{2}{*}{ Çok iyi } & $\mathrm{n}$ & 23 & 21 & 69 & 113 \\
\hline & & $\%$ & $20,4 \%$ & $18,6 \%$ & $61,1 \%$ & $100,0 \%$ \\
\hline & \multirow{2}{*}{ İyi } & $\mathrm{n}$ & 6 & 3 & 14 & 23 \\
\hline & & $\%$ & $26,1 \%$ & $13,0 \%$ & $60,9 \%$ & $100,0 \%$ \\
\hline & \multirow{2}{*}{ Orta } & $\mathrm{n}$ & 1 & 6 & 7 & 14 \\
\hline & & $\%$ & $7,1 \%$ & $42,9 \%$ & $50,0 \%$ & $100,0 \%$ \\
\hline \multirow{2}{*}{ Toplam } & & $\mathrm{n}$ & 30 & 30 & 90 & 150 \\
\hline & & $\%$ & $20,0 \%$ & $20,0 \%$ & $60,0 \%$ & $100,0 \%$ \\
\hline
\end{tabular}

$\chi^{2}=6.175 \mathrm{p}=0.186$

Tablo 8. Araştırma Grubunun Ekmek İsrafi Konulu Sosyal Sorumluluk Kampanya Tasarımlarının İçeriğiyle Hedef Kitleyi Bilgilendirme Düzeyine Ilişkin Görüşleri

Kampanyanın tasarımlarının içeriğiyle hedef kitleyi bilgilendirme düzeyine ilişkin soruya araştırmaya katılan grup içerisindeki (113 kişi) akademisyenlerin \%20,4 ü, uzmanların \% 18,6'sı ve hedef kitle olan öğrencilerin \% 61,1'i çok iyi; (23 kişi) akademisyenlerin \% 26,1'i, uzmanların \%13'ü ve hedef kitle olan öğrencilerin \%60,9'u iyi; (14 kişi) akademisyenlerin $\% 7,1$ 'i, uzmanların \% 42,9'u ve hedef kitle olan öğrencilerin \%50'si orta cevabını vermişlerdir. Akademisyen, uzman ve öğrencilere göre tasarımların içeriğiyle hedef kitleyi bilgilendirme düzeyi "çok iyi" olarak değerlendirilmiştir. İstatistiksel olarak da gruplara göre Tasarımların içeriğiyle hedef kitleyi bilgilendirme düzeyi konusunda görüş farklılığı bulunmamaktadır ( $p>0.05)$. Tablo 8'de görüldüğü üzere kampanyanın hedef kitleyi ekmek israfına yönelik olarak bilgilendirdiği ve bu konuda eğittiği söylenebilir. 


\begin{tabular}{|c|c|c|c|c|c|c|}
\hline & & & \multicolumn{3}{|c|}{ Grup } & \multirow[b]{2}{*}{ Toplam } \\
\hline & & & Akademisyen & Uzman & Öğrenci & \\
\hline \multirow{6}{*}{$\begin{array}{l}\text { 9) Tasarımlarda } \\
\text { verilmek istenen } \\
\text { mesajların akılda } \\
\text { kalıc1lığ1 sizce ne } \\
\text { derecedir? }\end{array}$} & \multirow{2}{*}{ Çok iyi } & $\mathrm{n}$ & 26 & 21 & 74 & 121 \\
\hline & & $\%$ & $21,5 \%$ & $17,4 \%$ & $61,2 \%$ & $100,0 \%$ \\
\hline & \multirow{2}{*}{ İyi } & $\mathrm{n}$ & 3 & 8 & 12 & 23 \\
\hline & & $\%$ & $13,0 \%$ & $34,8 \%$ & $52,2 \%$ & $100,0 \%$ \\
\hline & \multirow{2}{*}{ Orta } & $\mathrm{n}$ & 1 & 1 & 4 & 6 \\
\hline & & $\%$ & $16,7 \%$ & $16,7 \%$ & $66,7 \%$ & $100,0 \%$ \\
\hline \multirow{2}{*}{ Toplam } & & $\mathrm{n}$ & 30 & 30 & 90 & 150 \\
\hline & & $\%$ & $20,0 \%$ & $20,0 \%$ & $60,0 \%$ & $100,0 \%$ \\
\hline
\end{tabular}

$\chi^{2}=3.999 \quad \mathrm{p}=0.406$

Tablo 9. Araştırma Grubunun Ekmek İsrafi Konulu Sosyal Sorumluluk Kampanyasında Verilmek İstenen Mesajların Kalıcılığına İlişkin Görüşleri

Kampanya tasarımında verilmek istenen mesajların akılda kalıcılığına ilişkin soruya araştırmaya katılan grup içerisindeki (121 kişi) akademisyenlerin $\% 21,5$ 'i, uzmanların \% 17,4'ü ve hedef kitle olan öğrencilerin \% 61,2'si çok iyi; (23 kişi) akademisyenlerin \% 13'ü, uzmanların \% 34,8'ive hedef kitleolan öğrencilerin \% 52,2'si iyi; (6 kişi) akademisyenlerin \% 16,7'si, uzmanların $\% 16,7$ 'sive hedef kitle olan öğrencilerin \% 66,7'si orta cevabını vermişlerdir. Akademisyen, uzman ve öğrencilere göre tasarımlarda verilmek istenen mesajların akılda kalıcılığı "çok iyi" olarak değerlendirilmiştir. İstatistiksel olarak da gruplara göre tasarımlarda verilmek istenen mesajların akılda kalıcılığı konusunda görüş farklılığı bulunmamaktadır ( $p>0.05$ ). Tablo 9'da görüldüğü gibi kampanya tasarımında verilmek istenen mesajların akılda kalıcı ve hatırlanabilir olduğu söylenebilir.

Ekmek israfı konulu sosyal sorumluluk kullanılan görsel materyalin içeriğinin niteliğine (bütünlük, hedef kitleye uygunluk, mesajların doğruluğu ve geçerliliği, ve imla kuralları) yönelik öğretim elemanı uzman ve hedef kitleyi oluşturan öğrencilerin görüşleri alınmış ve sonuçlar tablo 10., 11. ve $12^{\prime}$ de verilmiştir. 


\begin{tabular}{|c|c|c|c|c|c|c|}
\hline & & & \multicolumn{3}{|c|}{ Grup } & \multirow[b]{2}{*}{ Toplam } \\
\hline & & & Akademisyen & Uzman & Öğrenci & \\
\hline \multirow{6}{*}{ Bütünlük } & \multirow{2}{*}{ Çok iyi } & $\mathrm{n}$ & 23 & 24 & 70 & 117 \\
\hline & & $\%$ & $19,7 \%$ & $20,5 \%$ & $59,8 \%$ & $100,0 \%$ \\
\hline & \multirow{2}{*}{ İyi } & $\mathrm{n}$ & 6 & 3 & 16 & 25 \\
\hline & & $\%$ & $24,0 \%$ & $12,0 \%$ & $64,0 \%$ & $100,0 \%$ \\
\hline & \multirow{2}{*}{ Orta } & $\mathrm{n}$ & 1 & 1 & 2 & 4 \\
\hline & & $\%$ & $25,0 \%$ & $25,0 \%$ & $50,0 \%$ & $100,0 \%$ \\
\hline \multirow{2}{*}{ Toplam } & & $\mathrm{n}$ & 30 & 28 & 88 & 146 \\
\hline & & $\%$ & $20,5 \%$ & $19,2 \%$ & $60,3 \%$ & $100,0 \%$ \\
\hline \multicolumn{7}{|c|}{$\chi^{2}=1.211 \quad \mathrm{p}=0.876$} \\
\hline \multicolumn{7}{|c|}{$\begin{array}{l}\text { Tablo 10. Araştırma Grubunun Ekmek İsrafı Konulu Sosyal Sorumluluk } \\
\text { Kampanyasında Kullanılan Görsel Materyalin Bütünlüğüne İlişkin Görüşleri }\end{array}$} \\
\hline \multicolumn{7}{|c|}{$\begin{array}{l}\text { Kampanyanın bütünlüğüne ilişkin soruya araştırmaya katılan grup içerisin- } \\
\text { deki (117 kişi) akademisyenlerin \% 19,7'si, uzmanların \% 20,5'i ve hedef } \\
\text { kitle olan öğrencilerin \% 59,8'i çok iyi; ( } 25 \text { kişi) akademisyenlerin \% } 24 \text { 'ü, } \\
\text { uzmanların \% } 12 \text { 'si ve hedef kitle olan öğrencilerin \% } 64 \text { 'ü iyi; (4 kişi) aka- } \\
\text { demisyenlerin \% } 25 \text { 'i, uzmanların \% } 25^{\prime} \text { 'i ve hedef kitle olan öğrencilerin } \\
\text { \%50'si orta cevabını vermişlerdir. Akademisyen, uzman ve öğrencilere } \\
\text { göre kampanyanın bütünlüğü "çok iyi" olarak değerlendirilmiştir. İstatis- } \\
\text { tiksel olarak da gruplara göre görsel materyalin içerik bütünlüğ konu- } \\
\text { sunda görüş farklılığı bulunmamaktadır (p>0.05). Tablo 39'da görüldüğü } \\
\text { gibi kampanyanın kullanılan görsel ve tipografi, içerik, verilmek istenen } \\
\text { mesajlar, temel tasarım öğe ve ilkeleri, seçilen mecralar ve tüm bu unsur- } \\
\text { ların hedef kitleye uygunluğu açısından bütünlüklü bir yapıya sahip olduğu } \\
\text { söylenebilir. }\end{array}$} \\
\hline
\end{tabular}




\begin{tabular}{|c|c|c|c|c|c|c|}
\hline & & & \multicolumn{3}{|c|}{ Grup } & \multirow[b]{2}{*}{ Toplam } \\
\hline & & & Akademisyen & Uzman & Öğrenci & \\
\hline \multirow{4}{*}{$\begin{array}{l}\text { Kampanyada verilen } \\
\text { mesajların doğruluğu } \\
\text { ve geçerliliği }\end{array}$} & \multirow{2}{*}{ Çok iyi } & $\mathrm{n}$ & 25 & 26 & 78 & 129 \\
\hline & & $\%$ & $19,4 \%$ & $20,2 \%$ & $60,5 \%$ & $100,0 \%$ \\
\hline & \multirow{2}{*}{ İyi } & $\mathrm{n}$ & 5 & 4 & 12 & 21 \\
\hline & & $\%$ & $23,8 \%$ & $19,0 \%$ & $57,1 \%$ & $100,0 \%$ \\
\hline \multirow{2}{*}{\multicolumn{2}{|c|}{ Toplam }} & $\mathrm{n}$ & 30 & 30 & 90 & 150 \\
\hline & & $\%$ & $20,0 \%$ & $20,0 \%$ & $60,0 \%$ & $100,0 \%$ \\
\hline
\end{tabular}

$\chi^{2}=0.221 \quad \mathrm{p}=0,895$

Tablo II. Araştırma Grubunun Ekmek İsrafi Konulu Sosyal Sorumluluk Kampanyasında Kullanılan Görsel Materyalin İçeriğinin Niteliği Doğrultusunda Hedef Kitleye Verilen Mesajların Doğruluğu ve Geçerliliğine İlişkin Görüşleri

Kampanyada kullanılan görsel materyalin içeriğinin niteliği bağlamında hedef kitleye verilen mesajların doğruluğu ve geçerliliğine ilişkin soruya araştırmaya katılan grup içerisindeki (129 kişi) akademisyenlerin \% 19,4'ü, uzmanların \% 20,2'si ve hedef kitle olan öğrencilerin \% 60,5'i çok iyi; (21 kişi) akademisyenlerin \%23,8'i, uzmanların \%19'u ve hedef kitle olan öğrencilerin \%57,1'i iyi; cevabını vermişlerdir. Akademisyen, uzman ve öğrencilere göre kampanya da kullanılan görsel materyallerin içeriğinin niteliği bağlamındahedef kitleyeverilen mesajların doğruluğuve geçerliliğini "çok iyi" olarak değerlendirilmiştir. İstatistiksel olarak da gruplara göre görsel materyalin verilen mesajın doğruluğu ve geçerliliği konusunda görüş farklılığı bulunmamaktadır ( $p>0.05)$. Tablo 11 'de görüldüğü gibi kampanya da kullanılan görsel materyallerin içeriğinin niteliği bağlamında hedef kitleye iletilmek için hazırlanan mesajların doğru ve güvenilir olduğu söylenebilir. 
Grup

Akademisyen Uzman Öğrenci Toplam

\begin{tabular}{|c|c|c|c|c|c|c|}
\hline \multirow{8}{*}{ Yazım Kuralları } & \multirow{2}{*}{ Çok iyi } & $\mathrm{n}$ & 26 & 27 & 79 & 132 \\
\hline & & $\%$ & $19,7 \%$ & $20,5 \%$ & $59,8 \%$ & $100,0 \%$ \\
\hline & \multirow{2}{*}{ İyi } & $\mathrm{n}$ & 2 & 1 & 4 & 7 \\
\hline & & $\%$ & $28,6 \%$ & $14,3 \%$ & $57,1 \%$ & $100,0 \%$ \\
\hline & \multirow{2}{*}{ Orta } & $\mathrm{n}$ & 2 & 0 & 5 & 7 \\
\hline & & $\%$ & $28,6 \%$ & $0,0 \%$ & $71,4 \%$ & $100,0 \%$ \\
\hline & \multirow{2}{*}{ Zayıf } & $\mathrm{n}$ & 0 & 2 & 2 & 4 \\
\hline & & $\%$ & $0,0 \%$ & $50,0 \%$ & $50,0 \%$ & $100,0 \%$ \\
\hline \multirow{2}{*}{ Toplam } & & $\mathrm{n}$ & 30 & 30 & 90 & 150 \\
\hline & & $\%$ & $20,0 \%$ & $20,0 \%$ & $60,0 \%$ & $100,0 \%$ \\
\hline
\end{tabular}

$\chi^{2}=4.877 \quad \mathrm{p}=0,560$

Tablo 12. Araştırma Grubunun Ekmek İsrafi Konulu Sosyal Sorumluluk Kampanyasında Kullanılan Görsel Materyallerin Içeriğinin Niteliği Bağlamında Yazım Kurallarına İlişkin Görüşleri

Kampanya da kullanılan görsel materyallerin içeriğinin niteliği bağlamında yazım kurallarına ilişkin soruya araştırmaya katılan grup içerisindeki (132 kişi) akademisyenlerin \%19,7'si, uzmanların \%20,5'i ve hedef kitle olan öğrencilerin \%59,8'i çok iyi; (7 kişi) akademisyenlerin \%28,6'sı, uzmanların \%14,3'ü ve hedef kitle olan öğrencilerin \%57,1'i iyi; (7 kişi) akademisyenlerin \% 28,6'sı ve hedef kitle olan öğrencilerin \% 71,4'ü orta; (4 kişi) uzmanların ve hedef kitle olan öğrencilerin \% 50'si zayıf cevabını vermişlerdir. Akademisyen, uzman ve öğrencilere göre kampanya da kullanılan görsel materyallerin içeriğinin niteliği bağlamında yazım kuralları "çokiyi" olarak değerlendirilmiştir. İstatistiksel olarak da gruplara göre görsel materyalin yazım Kuralları konusunda görüş farklılığı bulunmamaktadır ( $p>0.05)$. Tablo 12 'de görüldüğü üzere kampanyanın içeriğinin yazım kurallarına dikkat edilerek hazırlandığı söylenebilir. 


\section{Sonuç}

Sonuç olarak, araştırmaya katılan akademisyen, sektörde çalışan uzman ve hedef kitle olan öğrencilerin tamamına yakını ekmek israfını önlemeye yönelik yapılan sosyal sorumluluk kampanyasının hedef kitlesinin doğru saptandığını, kampanyanın problem çözüm ilişkisinin doğru kurgulandığını ve kampanya amacının anlaşıı bir biçimde sunulduğunu belirtmişlerdir. Bu doğrultuda, kampanya stratejisinin doğru belirlendiği görülmektedir.

Araştırmaya katılan akademisyen, sektörde çalışan uzman ve hedef kitle olan öğrencilerin büyük çoğunluğu kampanya tasarımında kullanılan renklerin dikkat çekici olduğunu ve hedef kitleye verilmek istenen mesajların ulaşmasında etkili olduğunu ifade etmişlerdir. Akademisyen, sektörde çaışan uzman ve hedef kitle olan öğrencilerin tamamına yakını kampanya tasarımında kullanılan tipografik öğelerin (yazı karakteri, font, punto vs.) okunur olduğunu ve bu öğelerin hedef kitleye iletilmek istenen mesajların açılanmasına uygun olduğunu vurgulamışlardır. Yine akademisyen, sektörde çalışan uzman ve hedef kitle olan öğrencilerin hemen hemen hepsi kampanya tasarımında kullanılan görsellerin (fotoğraf, illüstrasyon vs.) dikkat çekici, tasarımda kullanılan renk ve tipografiyle uyumlu bir bütünlüklü yapıya sahip olduğunu belirtmişlerdir.

Akademisyen, sektörde çalışan ve hedef kitle olan öğrencilerin çoğunluğu kampanya da hedef kitleye verilmek istenen mesajların akılda kalıcı olduğunu, kampanyada kullanılan görsellerle örtüştüğünü ve hedef kitleyi ekmek israfına yönelik olarak bilgilendirdiğini belirtmişlerdir. Buradan hareketle, ekmek israfını önlemeye yönelik yapılan sosyal sorumluluk kampanya tasarımının hedef kitleyi etkilediğini kampanyanın yaratıcı stratejisinde oluşturulan mesajların hedef kitlede bilinç uyandırarak onları ekmek israfı konusunda eğittiği belirlenmiştir.

Araştırmaya katılan akademisyen, sektörde çalışan uzman ve hedef kitle olan öğrencilerin tamamına yakını kampanya da kullanılan görsel materyalin içerik niteliğinin kampanyanın hedef kitlesine uygun, kampanyada verilen mesajların doğru, geçerli olduğunu ve Türkçe yazım kurallarına uygun bir bütünlüğe sahip olduğunu belirtmişlerdir. Bu bağlamda ekmek israfını önlemeye yönelik olarak yapılan sosyal sorumluluk kampanyasında kullanılan görsellerin içerik niteliğinin güncel, güvenilir ve kendi içinde hedef kitleye uygun bütünlükte olduğu sonucuna varılmaktadır. 


\section{Kaynakça}

Bayraktaroğlu, G. ve Illter B. (2007). “Sosyal Pazarlama: Engeller ve Öneriler.” Ege Akademik Bakış, 7 (I), II7-I32.

Karahan Ş. (2006). Sosyal Sorumluluk Kampanyalarının Tüketicilerin Satın Alma Tercihlerine Etkisi. Yüksek Lisans Tezi. Ege Üniversitesi Sosyal Bilimler Enstitüsü, İzmir.

Gülsoy, T. (1999). Reklam Terimleri ve Kavramları Sözlüğ̈̈. İstanbul: Adam Yayınları.

Elden, M. (2009). Reklam ve Reklamcilık. Istanbul: Say Yayıncılık.

Elden, M., Ulukök, Ö. ve Yeygel, S. (2005). Şimdi Reklamlar... (Birinci Baskı) İstanbul: Iletişim Yayınları.

Nayman, U. Ş. (2008). Sosyal İçerikli Reklam Kampanyalarının Grafik Tasarım IIlkeleri Bakımından Analizi ve Eğitsel Açıdan Değerlendirilmesi. Yüksek Lisans Tezi. Gazi Üniversitesi, Eğitim Bilimleri Enstitüsü, Ankara.

Özkaya, H. (1992). "Ekmeğin Beslenmedeki Önemi ve Ekmek Türlerinin Sağılk Açısından Farklılıkları." Unlu Mamüller Dünyası, 5, 9-I5.

Öten, M. ve Ünsal, S. (2006). “Şanlıurfa Yöresine Özgü Tırnaklı ve Açık Ekmeklerin Bazı Kimyasal Bileşimlerinin Belirlenmesi Üzerine Bir Araştırma. HR. Ü. Z. F. Dergisi. 10 (3/4), 57- 62.

Karaoğlu, M. ve Kotancılar, H. G. (200I). Tahıl Ürünlerinin Sağlığımız Açısından Önemi. Atatürk Üniversitesi Ziraat Fakültesi Dergisi, 32 (I), I0I-108.

Moriarty, E. Sandra. (199I). Creative Advertising Thoery and Practice. New Jersey: Prentice Hall, Englewood Cliffs.

Tepecik, A. (2002). Grafik Sanatlar Tarih - Tasarım - Teknoloji. Ankara: Detay Yayıncılık. 
Kampanya Tasarım Örnekleri

Afiş Tasarımları
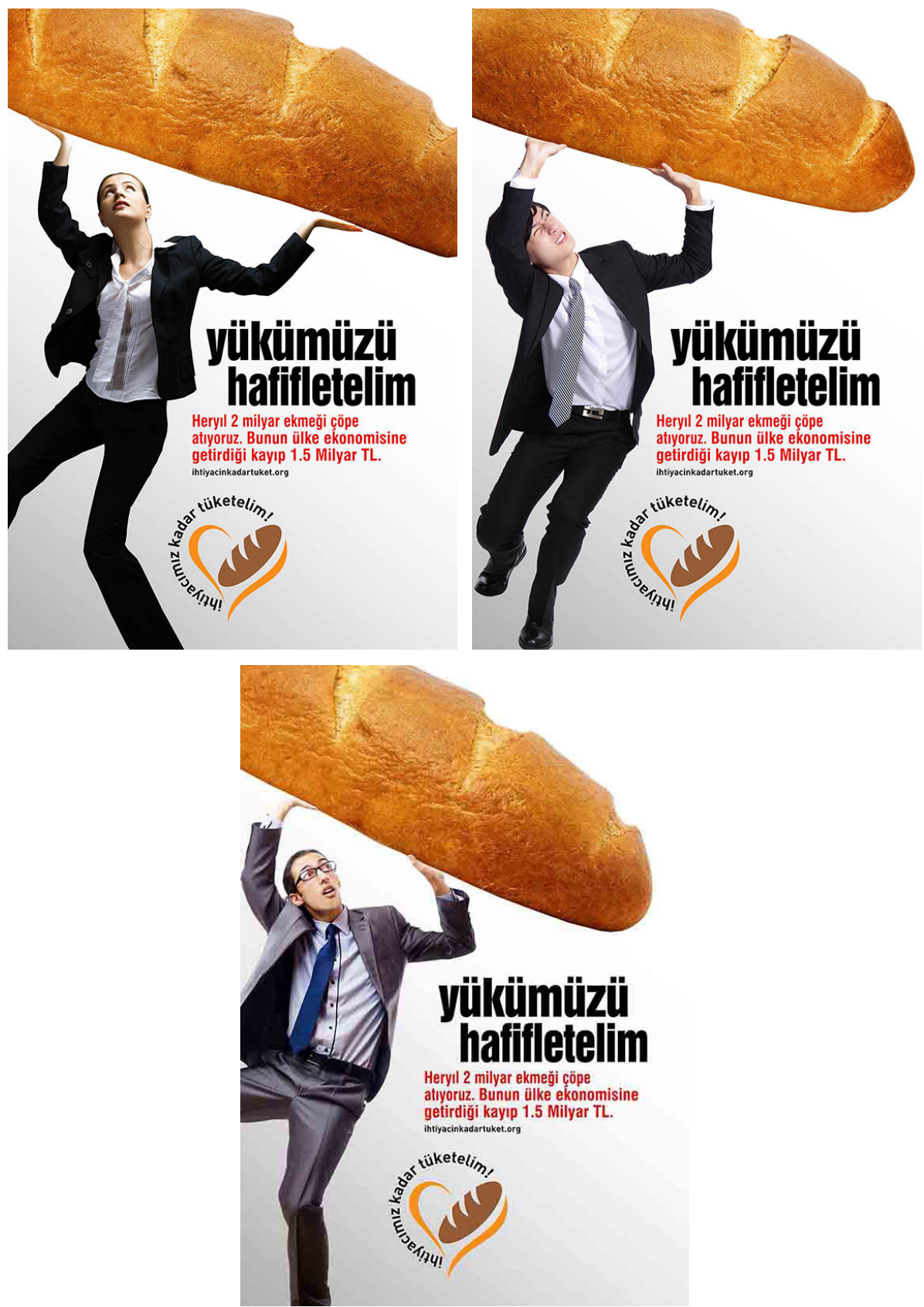


\section{Billboard Tasarımları}
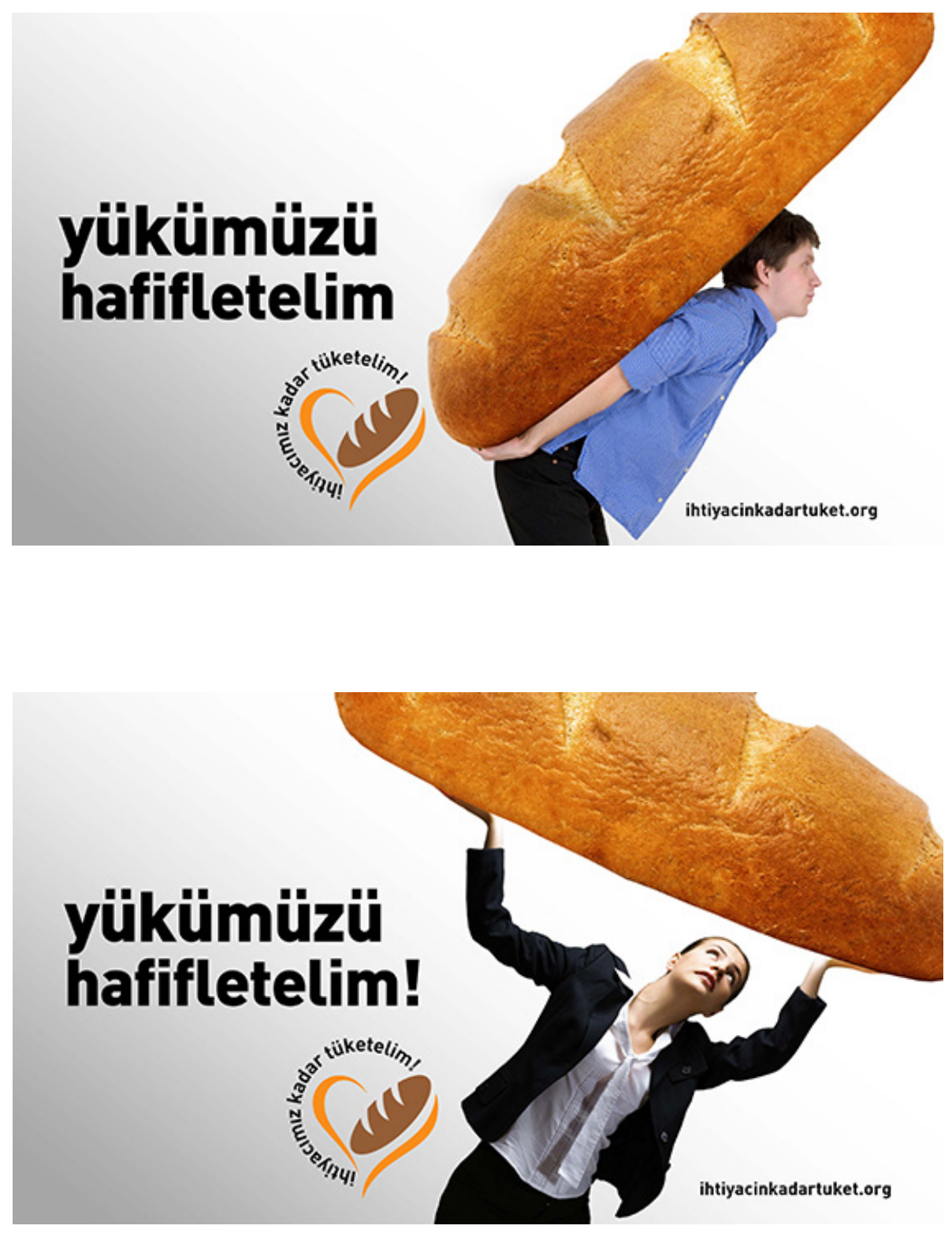


\section{Ambalaj Tasarımları}
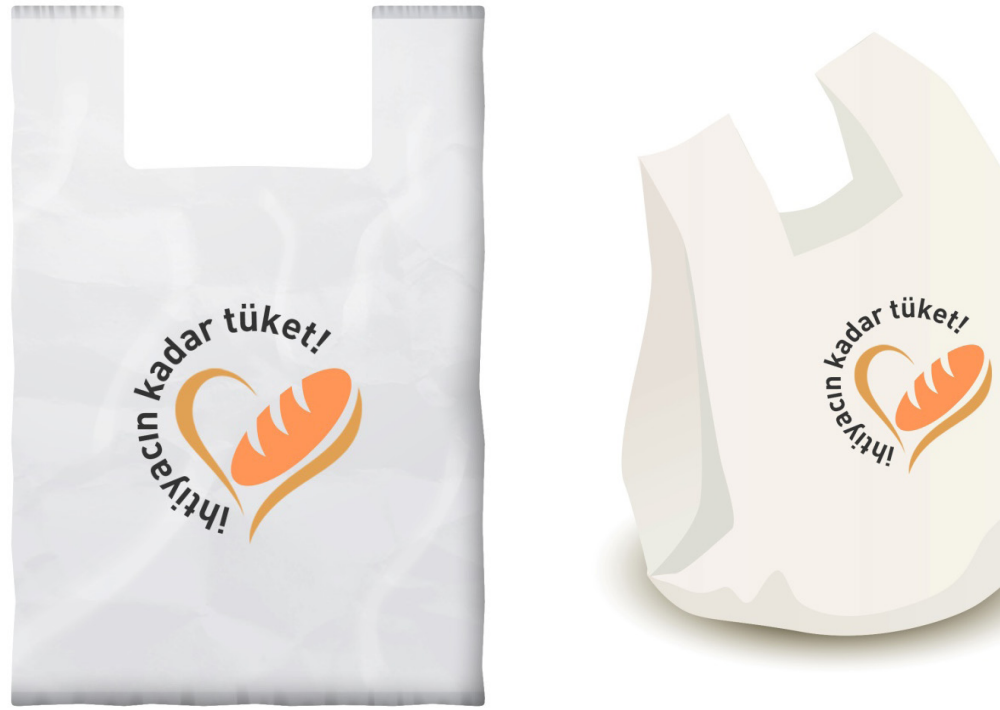

Araç Giydirme

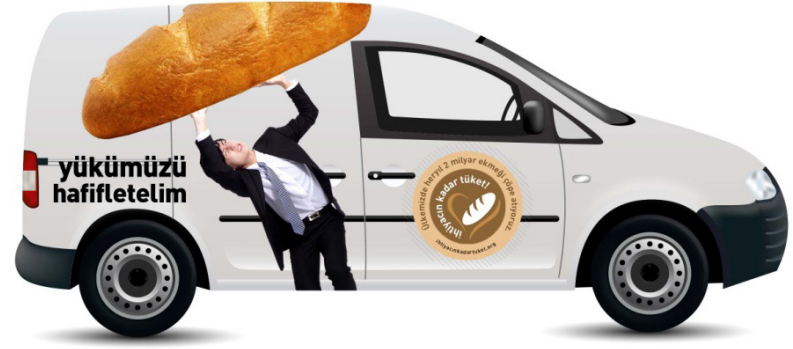

